\title{
Geriatrik popülasyonda serum okratoksin A düzeyleri
}

\author{
Belma Giray, Pınar Erkekoğlu, Suna Sabuncuoğlu, Sevtap Aydın, Gönül Şahin
}

ÖZET: Okratoksin A (OTA) en yaygın rastlanan mikotoksinlerden biridir. Çalışılan tüm hayvan türlerinde nefrotoksik olduğu gösterilmiş, immünosüpresif, hepatotoksik, teratojenik ve genotoksik etkilerinin bulunduğu bildirilmiştir. Birçok ülkede çeşitli gıdalarda OTA düzeyleri belirlenmiş olmakla birlikte, insanlardaki düzeylerine ilişkin sınırlı sayıda çalışma bulunmaktadır. Bu çalışmanın amacı, geriatrik popülasyonda serum OTA düzeylerini tespit etmek ve bu düzeylerin cinsiyet, beslenme alışkanlıkları ve vücut kitle indeksi ile ilişkisini belirlemektir. Akdeniz ve İç Anadolu Bölgelerinde yaşayan yaşlı bireylerden (yaş ortalaması: $72.8 \pm$ 5.6)" geriatrik çalışma grubu $(n=30)$ "oluşturulmuş ve serum OTA düzeyleri enzim immünoassay yöntemi ile tayin edilmiştir. Çalışma grubunda yer alan kadınlarda (0.601 $\pm 0.012 \mathrm{ng} /$ $\mathrm{ml})$ erkeklere $(0.335 \pm 0.096 \mathrm{ng} / \mathrm{ml})$ oranla yaklaşık 2 kat daha yüksek serum OTA düzeyleri tespit edilmiştir ( $p$ >0.05). İç Anadolu Bölgesinde yaşayan bireylerdeki serum OTA düzeylerinin Akdeniz Bölgesinde yaşayanlara oranla yaklaşık 2.5 kat daha yüksek olduğu bulunmuştur $(p<0.05)$. Bu farklar, cinsiyet ve bölgeler arasındaki değişik beslenme alışkanlıklarından ileri gelebilir. Diğer taraftan, tüm çalışma gruplarında günlük OTA alım düzeyleri düzenleyici otorite tarafından kabul edilen tolere edilebilir günlük alım düzeylerinin altında hesaplanmıştır. Gıdalar yoluyla OTA ile birlikte farklı mikotoksinlere temasın da söz konusu olabileceği ve OTA dahil maruz kalınan tüm mikotoksinlerin toplam etkilerine bağlı toksisitenin özellikle geriatrik popülasyonda önemli olabileceği göz ardı edilmemelidir.

ANAHTAR KELIMELER: Geriatrik popülasyon, okratoksin A, nefrotoksisite, ELISA, Türkiye

\section{GiRiş}

Mikotoksinler, uygun nem ve isı koşullarında g1da maddelerinde üreyebilen küflerin oluşturduğu toksik metabolitlerdir. Farklı gıdalar aracılığıyla büyük ölçüde temas edilebilen mikotoksinlerin insan sağlığı üzerinde son derece önemli toksik etkileri bulunmaktadır. Bu toksinler, günümüzde halk sağlığını tehdit etmenin yanı sıra ekonomide de ciddi kayıplara neden olmaktadır. Aflatoksin, okratoksin, trikotesen, patulin ve zearalenonlar başlica mikotoksinler arasında sıralanabilir $(\mathbf{1}, \mathbf{2})$.

Okratoksin A (OTA), Aspergillus ve Penicillium türü mantarlar tarafından üretilen ve çeşitli tahıl türleri başta olmak üzere farklı gıdalarda (süt ve süt ürünleri, baklagiller, kahve, taze ve kuru üzüm, olgunlaşmakta olan ve kurutulmuş meyvalar, şarap) tespit edilmiş bir okratoksin türüdür. Ayrica, bilhassa domuz eti, diğer hayvanların etleri ile organları ve anne sütünde de bulunmaktadir (1-5).
Deney hayvanlarında nefrotoksik etkisi kanıtlanmiş ve güçlü bir renal karsinojen olduğu belirlenmiştir (3-5). İnsanların OTA'ya teması, doğrudan mantar türünün geliştiği gıdaların tüketimiyle olduğu gibi, bunları tüketen hayvan ürünlerinin alınmasıyla da olmaktadır. Okratoksinlerin oluşturdukları klinik tabloya okratoksikoz denir. OTA'nın yaptığı renal lezyonlar, proksimal tübülün dejenerasyonu dahil, renal kortekste interstisyel fibrozis, glomerülün hiyalinizasyonu ve tübüler epitelin atrofisi ile birliktedir. OTA, ilk olarak proksimal tübüllerin epitel hücrelerinde böbrek büyüklüğünü azaltmadan dejeneratif değişikliklere neden olur ve bu hücrelerde daha sonra görülen apoptotik tipte lezyonun da nedenidir. Ayrıca, OTA maruziyeti böbrek korteksinin intertisyumunda eosinofilik, aselüler oluşumlara neden olur. Kronik maruziyette ise böbrek büyüklüğü azalır ve enflamatuar hücreler görülmeden difüz kortikal fibröz gelişir $(4,6)$.
KURUM

Hacettepe Üniversitesi

Eczacılık Fakültesi,

F.Toksikoloji Anabilim Dalı, Ankara, Türkiye

ILETIŞIM

Belma Giray

E-posta:

bgiray@hacettepe.edu.tr

Gönderilme:

01.03.2011

Revizyon:

21.03.2011

Kabul:

21.03.2011 
TABLO 1. Geriatrik Çalışma Grubuna ait Demografik Bilgiler

\begin{tabular}{|c|c|c|c|c|c|}
\hline & $n$ & Yaş & Boy (cm) & Kilo (kg) & VKI \\
\hline Kadın & 15 & $72.4 \pm 0.96$ & $158 \pm 0.01 a$ & $73.9 \pm 2.4$ & $29.5 \pm 0.8$ \\
\hline Erkek & 15 & $73.2 \pm 1.83$ & $167 \pm 0.02$ & $76.2 \pm 3.9$ & $27.2 \pm 1.1$ \\
\hline Tüm Grup & 30 & $72.8 \pm 1.03$ & $163 \pm 0.01$ & $75.0 \pm 2.3$ & $28.2 \pm 0.7$ \\
\hline
\end{tabular}

Değerler ortalama \pm standart hata olarak verilmiştir

a $p<0.05$ vs erkek grubu

OTA'nın immünosüpresif, hepatotoksik, nefrotoksik, teratojenik, apoptoz indükleyicisi, genotoksik ve lipit peroksidasyonu artırıcı etkileri olduğu gösterilmiştir $(\mathbf{7}, \mathbf{8})$. DNA kırılmaları, protein sentezinin inhibisyonu ve glikoneogenez, mitokondride oksidatif fosforilasyonun bozulması ve kanın pıhtılaşmasının engellenmesine neden olmasıyla insan sağlığı için büyük önem taşımaktadır. Fatal doz maruziyeti ile renal tübül nekrozu ve periportal karaciğer hücrelerinde pek çok patolojik değişiklik gözlenmiştir (6,9). OTA, Uluslararası Kanser Araştırma Enstitüsü (IARC) tarafından "Grup IIB" muhtemel karsinojen olarak sınıflandırılmıştır (5). Dolaylı karsinojen mekanizması aracılığıla epigenetik karsinojen olarak da adlandırılmaktadır. Ancak aynı zamanda DNA'ya doğrudan bağlanabilmesi nedeniyle doğrudan karsinojen olarak kabul edilmektedir $(4,5)$.

Çeşitli gıda ürünlerinde OTA düzeylerini tayin eden çok sayıda çalışma bulunmakla birlikte, insanlardaki düzeyin tayin edildiği çalışmalar sınırlıdır. Özellikle sağlıklı bireylerdeki bazal düzeylerin tespit edildiği ve yaş ile ilişkisinin değerlendirildiği çalışmalar az sayıdadır, genellikle yetişkin popülasyonda yapılmıştır (10-16). Palli ve ark. (13) tarafından İtalya'da sağlıklı yetişkinlerde (yaş aralığı 35-64) yapılan bir çalışmada, serum OTA örnekleri 0.2- $1.0 \mathrm{ng} / \mathrm{ml}$ olarak belirlenmiş; erkeklerde tayin edilen serum OTA düzeylerinin kadınlara oranla anlamlı ölçüde yüksek bulunduğu rapor edilmiştir. Hırvatistan'da yapılan bir diğer çalışmada, en yüksek plazma OTA düzeyinin erişkin bir popülasyonda, yaz döneminde $0.39 \mathrm{ng} / \mathrm{ml}$ olarak saptand1ğı bildirilmiştir (16). Assaf ve ark.'nın Lübnan' da yapmış oldukları çalışmada ortalama plazma OTA düzeyi $0.17 \mathrm{ng} / \mathrm{ml}$ olarak tespit edilmiş; cinsiyet ve yaş ile OTA düzeylerinde bir farklılık gözlenmediği rapor edilmiştir (14). Diğer taraftan, Çek Cumhuriyetinde yapılan bir diğer çalışmada ise 60 yaşın üzerindeki kadınlarda $1 \mathrm{ng} / \mathrm{ml}$ 'nin üstünde OTA tespit edilme oranının daha fazla olduğu rapor edilmiştir (12).

Geriatrik Çalışma Grubunda Hastalıkların Dağııımı

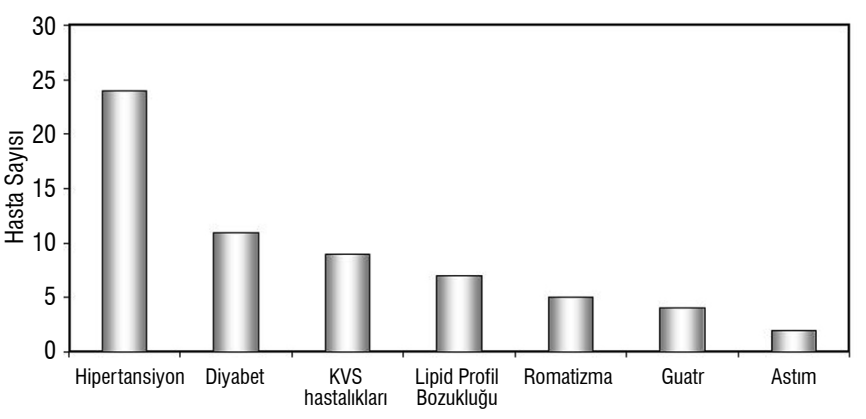

ŞEKiL 1. Geriatrik çalışma grubunda mevcut hastalıkların dağılımı KVS: Kardiyovasküler sistem
Ülkemizde ise bu doğrultuda yapılmış bir çalışmaya rastlanmamıştır Bu bilgiler ışı̆̆ında sunulan çalışmanın konusunu, yaşlı popülasyonda serum OTA düzeylerinin saptanması ve cinsiyet, beslenme alışkanlığı, vücut kitle indeksi ile birlikte değerlendirilmesi oluşturmaktadır.

\section{GEREÇ VE YÖNTEM Çalışma Grubu}

Türkiye' nin farklı bölgelerinde yaşayan (Akdeniz, n=16; İç Anadolu: $n=14)$, yaş ortalaması 65 ile 95 arasında değişen (72.8 \pm 5.6) bireylerden basit rastgele örnekleme yöntemi ile "geriatrik çalışma grubu (n=30)" oluşturulmuştur. Boy, kilo, beslenme alışkanlıkları mevcut kronik hastalıkları ve ailesel hastalık öyküsü standart bir anket uygulanarak alınmıştır. Ankette yer alan ve gıdaların ne sıklıkta tüketildiği ile bir seferde tüketilen gıda miktarına yönelik sorular ile beslenme alışkanlığına ilişkin bilgi elde edilmiştir. Çalışmaya dahil edilen yaşlı bireylerin herhangi bir karaciğer veya böbrek rahatsızlığının olmadığı da yapılan anket çalışması ile doğrulanmıştır. Her bir gönüllüden $10 \mathrm{ml}$ venöz kan örneği toplanmış, 800 xg'de 15 dakika santrifüj edilerek serum örnekleri ayrılmış ve analize dek $-20^{\circ} \mathrm{C}^{\prime}$ lik derin dondurucuda saklanmıştır. Bireylerden örnek toplanması yaz döneminde (Haziran-Temmuz aylarında) gerçekleştirilmiştir.

Çalışma, "Helsinki Deklerasyonu"na göre Hacettepe Üniversitesi Etik Kurulu'nca onaylanmıştır. Tüm bireylerin gönüllü olarak kan verdiklerini belirten imzalı aydınlatılmış onam formları kan örnekleri toplanmadan önce alınmıştır.

\section{Vücut kitle indeksinin hesaplanması}

Çalışma grubunda yer alan yaşlı bireylerden elde edilen bilgiler ışığında kilo ve boyları kaydedilmiş ve vücut kitle indeksleri (VKİ) aşağıda belirtilen şekilde hesaplanmıştır (17):

$$
\text { VKİ = Vücut Ağırlı̆̆ı (kg)/ (Boy) } 2 \text { (m) }
$$

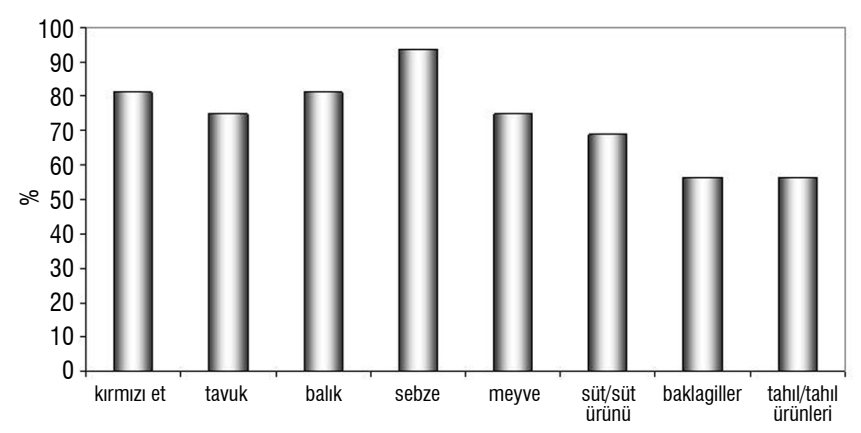

ŞEKiL 2. Akdeniz Bölgesi'ndeki geriatrik çalışma grubunun beslenme alışkanlıkları Gıda gruplarının bireylerin günlük diyetinde yer alıp almadığı ifade edilmektedir. 
İç Anadolu Bölgesindeki Geriatrik Popülasyonda Beslenme Alışkanlıkları

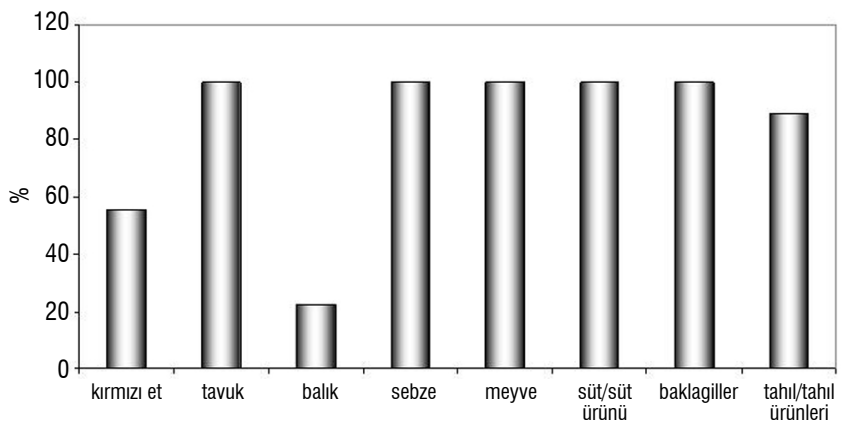

ŞEKiL 3. İç Anadolu Bölgesi'ndeki geriatrik çalışma grubunun beslenme alışkanlıkları Gıda gruplarının bireylerin günlük diyetinde yer alıp almadığı ifade edilmektedir.

\section{Okratoksin A düzeylerinin tayini}

Çalışma grubunda yer alan bireylerden alınan serum örnekleri, OTA düzeylerinin belirlenmesi amacıyla RIDASCREEN OTA Enzim İmmünoassay prosedürüne göre ekstre edilmiştir. Ekstraksiyonu takiben serum OTA düzeyleri RIDASCREEN OTA ELISA kitleri (Darmstadt, Almanya) kullanarak belirlenmiştir. Kullanılan OTA standartları 25-2025 ng/L arasındadır ve yöntemin deteksiyon limiti $25 \mathrm{ng} / \mathrm{L}^{\prime}$ dir. Geri kazanım deneyleri serum örneklerine $300 \mathrm{ng} / \mathrm{L}$ OTA eklenerek gerçekleştirilmiş ve geri kazanım oranı $\% 100.79 \pm 3.9$ olarak belirlenmiştir.

\section{Günlük okratoksin A alım düzeylerinin belirlenmesi}

Günlük OTA alım düzeyleri, OTA plazma/serum klerensi, vücuttaki biyoyararlanımı ve serum OTA düzeylerinden hareketle, aşağıda belirtilen hesaplama yöntemine göre hesaplanmiştır (18).

$\underline{k}_{0}=\mathrm{Cl}_{\mathrm{p}} \times \mathrm{C}_{\mathrm{p}} / \mathrm{A}$

$\underline{k}_{0}=\mathrm{Cp} \times 1.34$

$\mathrm{k}_{\underline{0}}=$ Günlük OTA Alım Düzeyi (ng/kg vücut ağırlı̆̆ı/ gün)

$\mathrm{Cl}_{\mathrm{p}}$ OTA plazma klerensi= $0.67 \mathrm{ml} / \mathrm{kg}$ vücut ağırlığı/gün

$\mathrm{C}_{\mathrm{p}}$ OTA serum konsantrasyonu $(\mathrm{ng} / \mathrm{ml})$

A: OTA biyoyararlanımı $=0.5$

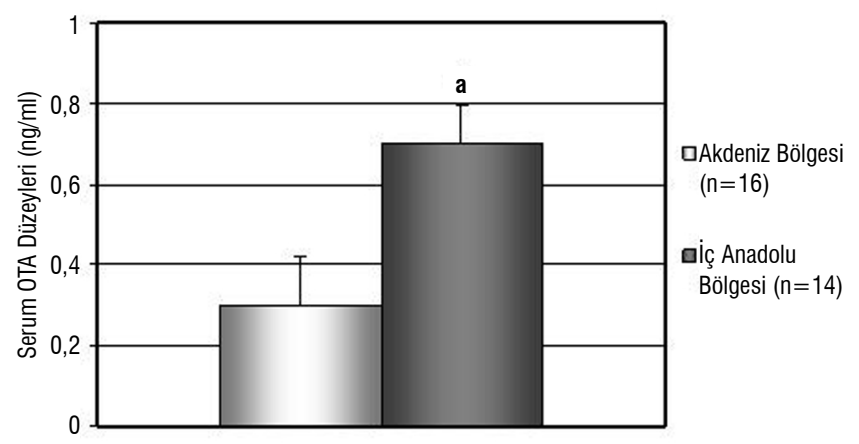

ŞEKiL 5. Geriatrik popülasyonda bölgelere göre Serum Okratoksin A düzeyleri a $p<0.05$

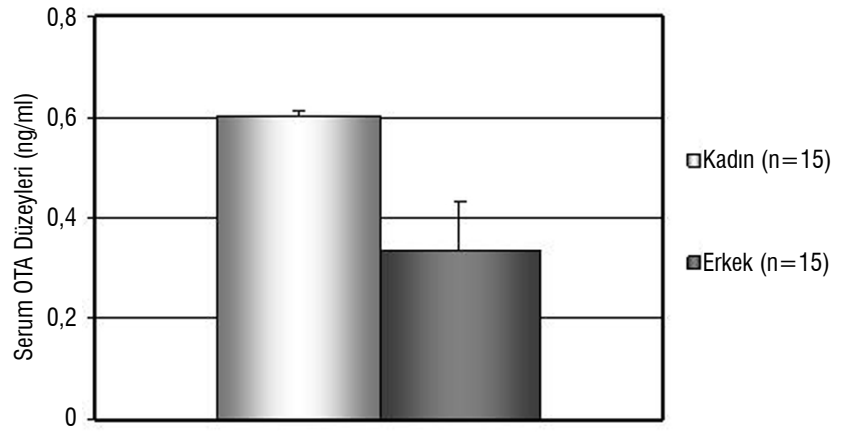

ŞEKiL 4. Kadın ve Erkeklerde Serum Okratoksin A düzeyleri

\section{Istatistiksel Analiz}

Gruplar arası farkların önem kontrolleri, ANOVA tek yönlü varyans analizi ve Student's t-testi uygulanarak test edilmiştir. Sonuçlar ortalama \pm standart hata (SEM) olarak verilmiştir. Değişkenler arasındaki korelasyonlar, normal dağılım gösteren değişkenler için «Pearson», normal dağılım göstermeyen değişkenler için "Spearman" korelasyon yöntemi ile incelenmiştir.

\section{BULGULAR}

Akdeniz ve İç Anadolu Bölgesinde yaşayan ve yaş ortalaması $72.8 \pm 5.6$ olan 30 kişiden kan örnekleri toplanmış ve serum OTA düzeyleri tayin edilmiştir. Geriatrik çalışma grubunda yer alan bireylere ait demografik veriler Tablo 1'de görülmektedir. Çalışma grubunda yer alan kadın ve erkek sayısı eşittir $(n=15)$ ve her iki grup arasında yaş, kilo ve VKI yönünden istatistiksel olarak önemli bir fark bulunmamıştır ( $p>0.05)$. Boy açısından ise gruplar arasında anlamlı bir fark mevcuttur $(p<0.05)$. Bireylerde mevcut hastalıkların dağılımı ve beslenmelerine ilişkin bilgi Şekil 1'de verilmiştir.

Beslenme alışkanlıkları yönünden çalışma grubu incelendiğinde, özellikle sebze ve meyve tüketimi yönünden fark olmadığ1, tüm çalışma grubunun bu besinleri tükettiği görülmüştür (Şekil.2 ve Şekil 3). İç Anadolu Bölgesi'nde kırmızı et ve balık tüketiminin Akdeniz Bölgesi'ne gore daha az olduğu, daha yüksek oranda tavuk tercih edildiği tespit edilmiştir. Tahıl ve tahıl ürünlerinin alım oranı da özellikle İç Anadolu Bölgesi'nde yüksektir.

Okratoksin A düzeyleri yönünden değerlendirme yapıldığın$\mathrm{da}$, serum OTA düzeylerinin erkeklerde $0.335 \pm 0.096 \mathrm{ng} / \mathrm{ml}$; kadınlarda $0.601 \pm 0.012 \mathrm{ng} / \mathrm{ml}$ olduğu, tüm çalışma grubunda da $0.453 \pm 0.078 \mathrm{ng} / \mathrm{ml}$ olarak belirlendiği görülmektedir (Şekil 4). Ortalama serum OTA düzeyleri minimum, maksimum ve ortanca değerleri ile birlikte Tablo $2^{\prime}$ de verilmiştir. Kadınlarda ölçülen düzeyler erkeklere oranla yaklaşık 2 kat fazla olmakla birlikte istatistiksel olarak anlamlı bulunmamıştır ( $\mathrm{p}>0.05)$. Günlük OTA alım düzeyleri de erkeklerde $0.449 \pm$ $0.129 \mathrm{ng} / \mathrm{kg} /$ gün; kadınlarda $0.805 \pm 0.160 \mathrm{ng} / \mathrm{kg} /$ gün ve tüm çalışma grubunda $0.607 \pm 0.105 \mathrm{ng} / \mathrm{kg}$ /gün olarak hesaplanmıştır (Tablo 3). Gruplar arası fark istatistiksel olarak önemli bulunmamıştır $(\mathrm{p}>0.05)$. Serum OTA konsantrasyonları ve günlük alım düzeyleri ile yaş ve VKI arasındaki ilişkilerin değerlendirilmesi amacıyla korelasyon katsayıları hesaplanmıs, 
TABLO 2. Serum Okratoksin A Düzeyleri

\begin{tabular}{|c|c|c|c|c|c|c|}
\hline & & $\mathbf{n}$ & Ortalama $\pm \mathrm{SH}$ & minimum & maksimum & Ortanca \\
\hline \multirow{3}{*}{ OTA Konsantrasyonu (ng/ml) } & Kadın & 15 & $0.601 \pm 0.012$ & 0.025 & 1.398 & 0.471 \\
\hline & Erkek & 15 & $0.335 \pm 0.096$ & 0.028 & 1.129 & 0.158 \\
\hline & Toplam & 30 & $0.453 \pm 0.078$ & 0.025 & 1.398 & 0.282 \\
\hline
\end{tabular}

Değerler ortalama \pm standart hata olarak verilmiştir

ancak istatistiksel olarak anlamlı bir ilişki bulunamamıştır (OTA konsantrasyonu- VKI için $\mathrm{r}=-0.047, \mathrm{p}>0.05$; OTA alım düzeyi- VKI için r=-0.047, p>0.05; OTA konsantrasyonu- yaş için $r=0.169, p>0.05$; OTA alım düzeyi- yaş için $r=0.169$, $\mathrm{p}>0.05)$.

Ayrıca, Akdeniz ve İç Anadolu Bölgelerinde yaşayan yaşlı bireylerde tayin edilen serum OTA düzeyleri karşılaştırılmış ve İç Anadolu Bölgesinde tayin edilen serum OTA düzeylerinin $(0.702 \pm 0.097 \mathrm{ng} / \mathrm{kg})$, Akdeniz Bölgesinde tayin edilen ortalama OTA düzeylerinden $(0.299 \pm 0.122 \mathrm{ng} / \mathrm{kg})$ anlamlı ölçüde yüksek $(\mathrm{p}<0.05)$ olduğu belirlenmiştir (Şekil 5). Her iki bölgede hesaplanan günlük alım düzeyleri arasındaki fark da (Akdeniz: $0.400 \pm 0.122 \mathrm{ng} / \mathrm{kg} /$ gün); İç Anadolu: $0.967 \pm 0.137 \mathrm{ng} /$ $\mathrm{kg}$ /gün) istatistiksel olarak anlamlı bulunmuştur $(\mathrm{p}<0.05)$.

\section{TARTIŞMA}

Bu çalışmada iki farklı bölgede yaşayan yaşlı bir grupta serum OTA düzeyleri tayin edilmiş, yaş, beslenme, vücut kitle indeksi ve cinsiyet ile olan olası ilişkileri değerlendirilmiştir. Tüm çalışma grubunda saptanan serum OTA konsatrasyonu 0.453 $\pm 0.078 \mathrm{ng} / \mathrm{ml}$ olarak belirlenmiştir. Dünyada birçok ülkede insanlardaki OTA düzeylerinin değerlendirildiği çalışmalar bulunmaktadır. Bu çalışmaların sonuçları devamlı olarak OTA maruziyetinin mevcut olduğuna işaret etmektedir. Sağlıklı bireylerde yapılan çalışmalar, Avrupa ülkelerinde ortalama serum veya plazma OTA düzeylerinin $1 \mathrm{ng} / \mathrm{ml}^{\prime}$ yi aşmadı̆̆ını göstermektedir $(\mathbf{1 3}, \mathbf{1 6})$. Bizim çalışmamızda bulunan değer de bu veri ile uyumludur. Çalışmalar incelendiğinde büyük bir kısmının yetişkin bireylerde yürütüldüğü, yaşlı grupta OTA düzeylerinin tayin edildiği sınırlı sayıda çalışma olduğu görülmektedir. Yaş ile OTA düzeyi ilişkisinin incelendiği çalışmalar az sayıdadır ve sonuçların uyumlu olmadığı görülmektedir. Mevcut çalışmalar, biyolojik örneklerde OTA bulunma insidansı ve yaş arasında az veya önemsiz bir ilişkinin varlığına işaret etmektedir (19). Birçok çalışma, yetişkinde kanda tayin edilebilir OTA düzeylerinde yaş ile bir farklılık görülmediğini göstermiştir $(\mathbf{1 3}, \mathbf{2 0 )}$. Bununla birlikte, İngiltere' de yapılan bir çalışmada 30-44 yaş aralığında saptanan OTA düzeylerinin $<30$ ve >45 yaş gruplarına göre daha yüksek olduğu saptanmıştır (10). Almanya' da yürütülen bir çalışmada 40 yaşın üstündeki erkeklerde OTA düzeyinin daha fazla olduğu, kadın- larda ise tersi bir durum gözlendiği bildirilmiştir (11). Çek Cumhuriyetinde yapılan bir diğer çalışmada ise 60 yaşın üzerindeki kadınlarda $1 \mathrm{ng} / \mathrm{ml}^{\prime}$ nin üstünde OTA tespit edilme oranının daha fazla olduğu rapor edilmiştir (12).

Ülkemizdeki duruma bakıldığında ise, sadece sağlıklı bireylerde OTA temasını değerlendiren bir çalışmaya rastlanmamıştır. Özçelik ve ark. (21), Isparta' da farklı üriner hastalıkları olan hastalarda (I. grup hemodiyaliz hastaları yaş ortalaması $43.7 \pm 15.2$, II. Grup peritoneal diyaliz hastaları yaş ortalamalar $47.9 \pm 12.5$, III. grup mesane kanser hastaları yaş ortalaması $56.8 \pm 9.7$, IV grup böbrek taşı hastaları yaş ortalaması $42.5 \pm$ 10) serum OTA düzeylerini tayin etmişler ve aynı bölgede yaşayan ve yaş ortalaması $41 \pm 13.7$ olan sağlıklı bireylerin (17 erkek, 23 kadın) sonuçları ile karşılaştırmışlardır. Sağlıklı bireylerde saptanan OTA düzeyleri $0.4 \pm 0.28 \mathrm{ng} / \mathrm{ml}^{\prime}$ dir. Yaş grubu farklı olmakla birlikte, bu değer bizim çalışmamızda tüm çalışma grubunda saptanan değer ile uyumludur. Akdeniz Bölgesi'nden toplanan örneklerde elde ettiğimiz serum OTA düzeyi sonuçları ile karşılaştırıldığında ise \%33 oranında fazla olduğu görülmektedir

Akdeniz Bölgesinde yetişkin $(n=89)$ ve çocuklarda $(n=21)$ OTA düzeylerinin tayini için tarafımızdan yapılan bir diğer çalışmada, gerek yetişkinlerde gerekse çocuklarda tayin edilen serum OTA düzeylerinin, sunulan çalışmada rapor edilen yaşlı gruptaki serum OTA düzeylerinden istatistiksel olarak anlamlı olmamakla birlikte daha düşük olduğu görülmektedir (22). Yaşlı grupta OTA düzeylerinin yüksek bulunması, OTA'nın gerek metabolizmasında, gerekse eliminasyonunda yaş ile birlikte bir azalma gözlenmesi ile açıklanabilir Ayrıca, yaşlı popülasyonun beslenme alışkanlığının daha genç gruba oranla farklılık göstermesi ile de ilişkili olabilir.

Sonuçlar, cinsiyete göre değerlendirildiğinde, kadınlarda belirgin oranda (yaklaşık 2 kat) yüksek OTA düzeyleri saptanmıştır. Ancak bireysel farklılıkların fazla olması ve denek sayısının azlığı nedeniyle gruplar arası fark istatistiksel olarak anlamlı bulunmamıştır. Cinsiyet ve serum/plazma tayin edilebilir OTA düzeyleri arasındaki ilişkiyi inceleyen çalışmaların da sınırlı olduğu görülmektedir (18). Çalışmaların birçoğunda herhangi bir ilişki bildirilmezken, İspanya' da yürütülen bir çalışmada bizim sonuçlarımızla uyumlu olarak kadınlarda yaz

TABLO 3. OTA Günlük Alım Düzeyler

\begin{tabular}{|c|c|c|c|c|c|c|}
\hline & & $\mathbf{n}$ & Ortalama $\pm \mathrm{SH}$ & minimum & maksimum & Ortanca \\
\hline \multirow{3}{*}{$\begin{array}{l}\text { Günlük OTA alım düzeyleri (ng/ } \\
\text { kg/gün) }\end{array}$} & Kadın & 15 & $0.805 \pm 0.160$ & 0.034 & 1.873 & 0.631 \\
\hline & Erkek & 15 & $0.448 \pm 0.129$ & 0.037 & 1.512 & 0.212 \\
\hline & Toplam & 30 & $0.607 \pm 0.105$ & 0.034 & 1.873 & 0.378 \\
\hline
\end{tabular}

Değerler ortalama \pm standart hata olarak verilmiştir. 


\section{Serum Ochratoxin A Levels in Geriatric Population}

SUMMARY: Ochratoxin A (OTA) is one of the most abundant food-contaminating mycotoxins. It is nephrotoxic to all animal species studied and also immunosuppressive, hepatotoxic, teratogenic and genotoxic. There is limited number of studies on the levels of OTA in humans. The aim of this study was to determine serum levels of OTA in geriatric population as well as to establish its relation with sex, feeding habits and body mass index. Serum OTA levels were measured by enzyme immunoassay in geriatric study group (mean age: $72.8 \pm 5.6$, $n=30$ ) living in Mediterranean and Central Anatolia regions. We found that the mean OTA level in women $(0.601 \pm 0.012 \mathrm{ng} / \mathrm{ml}) \mathrm{was}$ higher (approximately 2 fold) than in men $(0.453 \pm 0.078 \mathrm{ng} / \mathrm{ml})(p>0.05)$. Serum OTA levels in Central Anatolia were found to be higher than Mediterranean Region $(2.5$ fold $)(p<0.05)$ possibly due to feeding habit differences between the sexes and regions. On the other hand, daily intake levels of OTA in all study groups were calculated below the tolerable daily intake levels approved by regulatory authorities. It can be considered that the exposure to different mycotoxins along with OTA can cause synergistic or additive effects particularly in geriatric population.

KEY WORDS: Geriatric population, ochratoxin A, nephrotoxicity, ELISA, Turkey

döneminde olmak üzere erkeklere oranla istatistiksel olarak anlamlı ölçüde yüksek OTA düzeyleri tayin edilmiştir (15). Yaz döneminde serum/plazma OTA düzeylerinin yüksek bulunmasında da, nemli ve sıcak ortamda gidaların OTA ile kontaminasyon riskinin fazla olması ile kontamine gıdaların tüketim oranının artmasının rolü olacağı bildirilmektedir $(\mathbf{1 5}, \mathbf{1 9 )}$. İtalya' da ise tam tersine erkeklerde ölçülen OTA düzeylerinin daha yüksek olduğu rapor edilmektedir (13). Bizim çalışmamızda bildirmiş olduğumuz sonuç, kadınların tahıl ürünleri başta olmak üzere OTA ile kontamine gıdaları daha fazla tüketiyor olması ile açıklanabilir. Diğer taraftan, VKI ile serum OTA düzeyleri arasında önemli bir ilişki saptanmamıştır.

Tüm çalışma grubunda ortalama günlük OTA alım düzeyleri $0.607 \pm 0.105 \mathrm{ng} / \mathrm{kg} /$ gün olarak hesaplanmıştır. Kadınlarda hesaplanan düzey $0.805 \pm 0.160 \mathrm{ng} / \mathrm{kg} /$ gün ve erkeklerde $0.449 \pm 0.129 \mathrm{ng} / \mathrm{kg} /$ gün olarak belirlenmiştir. Cinsiyete göre günlük alım düzeylerinde gözlenen bu fark, denek sayısının azlığı ve bireysel farklılıklar nedeniyle istatistiksel olarak anlamlı bulunmamıştır. İnsanlarda OTA için tolere edilebilir günlük alım düzeyi (TDI) Dünya Sağlık Örgütü tarafından 14 $\mathrm{ng} / \mathrm{kg}$ /gün olarak bildirilmiştir (23). Gida Toksikolojisi ve Risk Değerlendirmesi Nordik Çalışma Grubu tarafından yapılan değerlendirmede kabul edilen TDI 5 ng/kg/gün'dür (24). Kanada Uzmanlar Grubu da TDI için 1.2-5.7 ng/kg/gün değerini önermektedir (25). Gerek tüm grupta, gerekse kadın ve erkek gruplarında hesaplanan değerlerin her üç değerden de düşük olduğu görülmektedir.

Çalışma kapsamında yer alan Akdeniz ve İç Anadolu Bölgelerinden toplanan kan örneklerinde ölçülen serum OTA konsantrasyonlarının ve hesaplanan günlük OTA alım düzeylerinin İç Anadolu'da Akdeniz Bölgesine oranla önemli ölçüde yüksek bulunması (yaklaşık 2.5 kat) beslenme alışkanlıklarındaki farklılık ile açıklanabilir. Nitekim, OTA kontaminasyonunun fazla görülebildiği tahıl ve tahıl ürünleri ile süt/süt ürünleri ve baklagillerin tüketim sıklığının özellikle İç Anadolu Bölgesinde yüksek olduğu görülmektedir. Bu durum, OTA maruziyetinde beslenme alışkanlıklarının önemini vurgular niteliktedir.

Sonuç olarak, az sayıda olmakla birlikte çalışma kapsamında yer alan tüm yaşlı bireylerde tayin edilebilir düzeyde OTA varlığ1 tespit edilmiştir. Tayin edilen OTA konsantrasyonlarında istatistiksel olarak önemli olmamakla birlikte kadınerkek grubu arasında büyük oranda farklılık gözlenmiştir. Bölgeler arasında da muhtemelen tüketilen gıdaların faklılığına bağlı olarak önemli düzeyde OTA düzeylerinin değiştiği belirlenmiştir. Günlük alım düzeyleri hesaplandığında benzer faklılıklar saptanmış, ancak ortalama OTA günlük alım düzeylerinin başta Dünya Sağlık Örgütü olmak üzere uzman kuruluşlar tarafından bildirilen TDI değerlerinin altında olduğu görülmüştür. Bununla birlikte, g1dalar yoluyla farklı mikotoksinlere (aflatoksinler, fumonisin, patulin) temasın da söz konusu olabileceği ve maruz kalınan tüm mikotoksinlerin toplamsal etkilerine bağlı toksisitenin önemli olabileceği göz ardı edilmemelidir. Özellikle OTA düzeyleri yüksek olan bireylerde başta nefrotoksik etkiler olmak üzere organizmada istenmeyen etkilerin oluşabileceği dikkate alınmalı ve gıdaların OTA dahil tüm mikotoksinlerle kontaminasyonunun önlenmesi için gerekli önlemler alınmalıdır.

Teşekkür: Bu çalışma Hacettepe Üniversitesi Bilimsel Araştırmalar Birimi tarafından desteklenmiştir (Proje No: 0401301002).

\section{KAYNAKLAR}

1. Bennett JW, Klich M. Mycotoxins. Clin Microbiol Rev 2003;16 (3): 497- 516.

2. Fink-Gremmels J. Mycotoxins: their implications for human and animal health. Vet Q 1999;21 (4): 115-120.

3. Peraica M, Radić B, Lucić A, Pavlović M. Toxic effects of mycotoxins in humans. Bull World Health Organ 1999;77 (9): 754-766.

4. Bayman P, Baker JL. Ochratoxins: a global perspective. Mycopathologia 2006; 162 (3): 215-223.

5. Pfohl-Leszkowicz A, Manderville RA. Ochratoxin A: An overview on toxicity and carcinogenicity in animals and humans. Mol Nutr Food Res 2007;51 (1): 61- 99.

6. Fuchs R, Peraica M. Ochratoxin A in human kidney diseases. Food Addit Contam 2005; 22 Suppl. 1: 53-57.

7. Atroshi F, Biese I, Saloniemi H, Ali-Vehmas T, Saari S, Rizzo A, Veijalainen P. Significance of apoptosis and its relationship to antioxidants after ochratoxin A administration in mice. J Pharm Sci 2000; 3 (3): 281-291. 
8. Soyoz M, Özcelik N, Kılınç I, Altuntaş I. The effects of ochratoxin A on lipid peroxidation and antioxidant enzymes: A protective role of melatonin. Cell Biol Toxicol 2004;20 (4): 213-219.

9. Pitt JI. Toxigenic fungi: Which are important. Med Myology 2000; 38 Suppl. 1: 17-22.

10. Gilbert J, Brereton $P$, MacDonald S. Assessment of dietary exposure to ochratoxin A in the UK using a duplicate diet approach and analysis of urine and plasma samples. Food Addit Contam 2001;18 (12): 1088-1093.

11. Hadlok M. Human ochratoxicosis in Germany updating 1993. In: Human ochratoxicosis and its pathologies. Editors: Creppy EE, Castegnaro M, Dirheimer G, Eurotext. Montrouge. 1993, pp 141-145.

12. Ruprich J, Ostrý V. Study of human exposure to ochratoxin A and assessment of possible sources. Cent Eur J Public Health 1993;1(2): 46-48.

13. Palli D, Miraglia M, Saieva $C$, Masala G, Cava E, Colatosti M, Corsi AM, Russo A, Brera C. Serum levels of ochratoxin A in healthy adults in Tuscany: correlation with individual characteristics and between repeat measurements. Cancer Epidemiol Biomarkers Prev 1999;8(3): 265-269.

14. Assaf H, Betbeder AM, Creppy EE, Pallardy M, Azouri H. Ochratoxin A levels in human plasma and foods in Lebanon. Hum Exp Toxicol 2004; 23(10): 495-501.

15. Burdaspal PA, Legarda TM., Datos sobre la presencia de ochratoxina A en plasma humano en Espana. Alimentaria 1998;292: 103-109.

16. Peraica M, Domijan AM, Matasin M, Lucic A, Radic B, Delas F, Horvat M, Bosanac I, Balija M, Grgicevic D, Variations of ochratoxin A concentration in the blood of healthy populations in some Croatian cities. Arch Toxicol 2001;75(7): 410-414.
17. World Health Organization, The problem of overweight and obesity. In: WHO Technical report series, Obesity: preventing and managing the global epidemic. WHO Press. Geneva. 2000, pp 6-13.

18. Breitholtz A, Olsen $M$, Dahlbäck A, Hult K. Plasma ochratoxin A levels in three Swedish populations surveyed using an ion-pair HPLC technique. Food Addit Contam 1991;8(2): 183-92.

19. Scott PM. Biomarkers of human exposure to ochratoxin A. Food Addit Contam 2005; 22 Suppl. 1: 99-107.

20. Scott PM, Kanhere SR, Lau BP, Lewis DA, Hayward S, Ryan JJ, Kuiper-Goodman T. Survey of Canadian human blood plasma for ochratoxin A. Food Addit Contam 1998;15(5): 555-562.

21. Ozcelik N, Kosar A, Soysal D, Ochratoxin A in human serum samples collected in Isparta-Turkey from healthy individuals and individuals suffering from different urinary disorder. Toxicol Lett 2001;121(1): 9-13.

22. Sabuncuoğlu S, Erkekoğlu $P$, Aydın S, Şahin G, Giray B. Seasonal variation in serum ochratoxin levels in healthy subjects living in Mediterranean Region of Turkey. In: Abstract Book of 122nd Annual Meeting and Exposition. AOAC International Press. Dallas, Teksas. 2008, pp. 128.

23. World Health Organization, Ochratoxin A. In: WHO Technical report Series, Evaluation of Certain Food Additives and Contaminants. WHO Press. Geneva. 2007, pp.169-180.

24. The Nordic Working Group on Food Toxicology and Risk Evaluation. Health evaluation of ochratoxin A in food products. In: Nordiske Seminar-og Arbejdsrapporter 545. Nordic Council of Ministers. Copenhagen. 1991, pp. 1-26.

25. Kuiper-Goodman $T$. Uncertainties in the risk assessment of three mycotoxins: aflatoxin, ochratoxin, and zearalenone. Can J Physiol Pharmacol 1990;68(7): 1017-1024. 